\title{
Analysis of rice farming in tidal swampland, Tulang Bawang Regency, Lampung Province
}

\author{
Slameto $^{1^{*},}$ EM Jannah ${ }^{1}$, Meidaliyantisyah ${ }^{1}$ and W Wibawa ${ }^{1}$ \\ ${ }^{1}$ Lampung Assessment Institute of Agricultural Technology (Lampung AIAT), Jl. Hi. \\ Zainal Abidin Pagar Alam No.1a, Rajabasa, Bandar Lampung City, Lampung \\ Province, Indonesia
}

*Corresponding authors: islameto@yahoo.co.id

\begin{abstract}
Rice is still a strategic commodity in Indonesia. The need for rice to fulfill staple food every year tends to increase in line with the rate of population growth in Indonesia. Lampung Province government continues to strive for various programs to fulfill food. One of the efforts made is optimizing the use of marginal land in the swampland. The swampland area in Lampung is about 162,930 ha, consisting of 68,900 ha of tidal swampland and 94,030 ha of lowland swamps. Lampung potential swampland, has the opportunity to meet food needs, especially rice. Problems of swampland rice farming which commonly found are environmental stress related to water and land management, unadaptive rice commodities and applying appropriate cultivation technology. Swampland rice farming is expected to provide added value and benefits for farmers. This study aims to analyze rice farming in the tidal swampland of Tulang Bawang Regency, Lampung Province. The farm study was carried out by planting rice on a 1 ha tidal swampland. The rice planted is the existing local rice varieties. The study was carried out in the second planting season. The results of the study showed that the growth and production of rice is quite good. Rice farming in the tidal wetland provides an advantage over an $\mathrm{R} / \mathrm{C}$ ratio of 1.46 and an $\mathrm{R} / \mathrm{C}$ ratio of 1.72 . So that rice farming in the tidal swampland is feasible.
\end{abstract}

\section{Introduction}

Rice is a strategic commodity in Indonesia. The need for rice to meet basic needs every year tends to increase in line with the rate of population growth in Indonesia. The government continues to strive to meet the basic needs of the population for rice through a superior program to increase these commodity products. Superior programs that have been initiated by the Ministry of Agriculture for several years include the Increase of National Rice Production $(P 2 B N)$, special efforts (Upsus), as well as accelerated planting movements and sub-optimal land optimization (Sapira), to the food estate program. These various strategies are used to meet national rice needs [1].

The area of tidal land in Indonesia reaches 20.11 million ha of which 2.07 million ha of potential land, 6.71 ha of acid sulphate land, 10.89 million ha of peat land and 0.44 ha of saline land are scattered mainly on the island of Sumatra. Kalimantan, and Papua [2]. The tidal area covering an area of 9.53 million ha which has the potential for agricultural areas, but which has been reclaimed until year two thousand is only around 4.18 million hectares [3]. However, efforts to optimize tidal swamp land must look at the existing obstacles and constraints related to the characteristics of the land. The problems encountered in swamp rice farming are environmental stress related to land and water management, non-adaptive rice commodities and the application of appropriate cultivation technology. 
According to [4], tidal land is a land that is fragile and full of problems such as the presence of pyrite content, weak buffering capacity, the cations are easily washed away, sulfidic content pyrite in the river bed and along the coast [5]. The success of tidal swamp land optimization is closely related to proper management of acid sulphate soil properties, pyrite compounds, tidal inundation conditions, groundwater depth, acidity of water inundating the land $[2,4]$. For this reason, efforts to increase productivity should emphasize the application of technological innovation [6]. It is necessary to identify constraints in the field. [7] saw the low productivity of barriers to soil fertility, water availability, climate, and the handling of the problem must be comprehensive and efficient. In addition, other things that should be available are the encouragement of superior seeds use that are able to accelerate the increase in rice production and preferred by the community really needs [8], rotating varieties [9], high quality and economical varieties [10,11], varieties that are resistant to biotic and abiotic stress [12], varieties that are suitable for agroecosystems [13], varieties with optimal results on specific lands [14], hybrid types of rice [15], as well as varieties whose preferences are very popular.

In line with the Ministry of Agriculture, Lampung Province Government continues to pursue various food fulfillment programs. Apart from technically irrigated rice fields and rainfed rice fields, one of the efforts made is by optimizing the use of marginal land in swamps which have the opportunity to become new land to support food. The area of swamps in Lampung is around 162,930 ha, consisting of 68,900 ha of tidal swamps and 94,030 ha of lowland swamps [16].

Lampung's potential swamps are mainly scattered in the Lampung region, one of which is the Tulang Bawang area, which has the opportunity to meet food needs, especially rice. The area of Tulang Bawang Regency consists of 15 sub-districts with an area of 342,632 ha, and Dente Teladas District is the largest sub-district (68,565 ha). In 2019 the rice harvested area reached 51,559.24 ha with rice production reaching $217,894.24$ tons, the average productivity of rice in the Tulang Bawang Regency area was $4,226 \mathrm{~kg} / \mathrm{ha}$ [17].

So that by looking at the potential, opportunities and handling of these obstacles, rice farming in swamps is expected to become a source of farmers' livelihood. For this reason, this study aims to analyze rice farming in the tidal swamps of Tulang Bawang Regency, Lampung Province.

\section{Material and Method}

This research was a field research with a combination of observation and survey methods. The location was in Teladas Village, Dente Teladas District, Tulang Bawang Regency. The location was determined deliberately with the consideration that the area is a center for rice production and agricultural land in the form of swamps which are affected by tides. The farmers were members of the Karyatani farmer group, Marga Jaya, Teladas Village, Dente Teladas District, Tulang Bawang Regency. To ensure rice farming, observations were made by planting a rice demonstration plot in a 1 ha tidal swamp. The rice planted was a local existing rice variety that is often planted (Cilamaya Muncul or Ciherang varieties). The research was carried out in the second planting season in AprilJuly 2020.

To analize the farming system, the data was collected by means of structured interviews using a list of questions (questionnaire) according to the research objectives. The number of respondents was 30 people who were taken randomly from the farmer groups based on information from local extension agents. The aspects studied included land characteristics, cropping patterns in swamps, farmer characteristics, and description of rice farming. The data analysis emphasizes the feasibility analysis of rice farming in swamps by analyzing the $\mathrm{R} / \mathrm{C}$ ratio in the rice production cycle. Data analysis was performed using descriptive statistics [18].

\section{Results and discussions}

\subsection{Land conditions at the Research Location}

Before the implementation of the demonstration plot for rice farming in swamps, observations were made of the land conditions in Teladas Village, Dente Teladas District, Tulang Bawang Regency. Initial observations by taking soil sample at the research location and the results of the analysis are 
presented in Table 1. The results of the soil analysis show that the soil type is often inundated in the form of swampy rice fields. Soil acidity conditions tend to be acidic, organic matter content is quite high. The available soil nutrient content is quite high, such as available $\mathrm{P}, \mathrm{Na}, \mathrm{Ca}$ and $\mathrm{K}$, base saturation and high cation exchange capacity. The soil structure tends to be crumbly, loose, black soil color which indicates high organic matter. So it can be concluded that the soil conditions are quite fertile in the research area.

Table 1. Results of Analysis of Soil Samples in Teladas Village Research Sites, Dente Teladas District, Tulang Bawang Regency, 2020.

\begin{tabular}{|c|c|c|c|}
\hline No & Parameter test & Value & Methode \\
\hline 1. & $\mathrm{pH} \mathrm{H}_{2} \mathrm{O}$ & 5,76 & Potensiometric $(1: 5)$ \\
\hline 2. & $\mathrm{pH} \mathrm{KCI}$ & 5,09 & Potensiometric (1:5) \\
\hline 3. & $\%$ C-Organic & 3,69 & Walkley\&Black, Spektrophotometric \\
\hline & $\%$ Nitrogen & 0,25 & Kjeldahl, Titration \\
\hline 5. & $\mathrm{C} / \mathrm{N}$ & 14,76 & - \\
\hline 6. & $\mathrm{P}_{2} \mathrm{O}_{5}$ Tersedia $(\mathrm{ppm})$ & 30,45 & Bray, Spektrophotometric \\
\hline 7. & $\mathrm{P}$ Potential $\left(m g \mathrm{P}_{2} \mathrm{O}_{5} / 100 \mathrm{gr}\right)$ & 115,29 & Extract HCI $25 \%$, Spektrophotometric \\
\hline 8. & $\mathrm{~K}$ Potential (mg K $2 \mathrm{O} / 100 \mathrm{gr})$ & 27,64 & Extract $\mathrm{HCI} 25 \%$, AAS \\
\hline 9. & $\begin{array}{l}\text { Exchangeable acid } \\
\text { Al-e }(\mathrm{cmol} / \mathrm{Kg})\end{array}$ & 0,29 & KCI 1M, Titration \\
\hline & $\begin{array}{l}\text { Exchangeable acid } \\
\mathrm{H}-\mathrm{e}(\mathrm{cmol} / \mathrm{Kg})\end{array}$ & 0,25 & KCI 1M, Titration \\
\hline & K-e (cmol/Kg) & 0,48 & Amonium Acetate $1 \mathrm{M} \mathrm{pH} 7$, AAS \\
\hline & Na-e $(\mathrm{cmol} / \mathrm{Kg})$ & 0,59 & Amonium Acetate $1 \mathrm{M} \mathrm{pH} \mathrm{7,} \mathrm{AAS}$ \\
\hline 13. & Ca-dd $(\mathrm{cmol} / \mathrm{Kg})$ & 6,61 & Amonium Acetate $1 \mathrm{M} \mathrm{pH} \mathrm{7,} \mathrm{AAS}$ \\
\hline 14. & Mg-e $(\mathrm{cmol} / \mathrm{Kg})$ & 1,23 & Amonium Acetate $1 \mathrm{M} \mathrm{pH} \mathrm{7,} \mathrm{AAS}$ \\
\hline 15. & KTK $(\mathrm{cmol} / \mathrm{Kg})$ & 27,52 & Destilation Percolate, Titration \\
\hline 16. & $\%$ Base saturation & 32,38 & - \\
\hline
\end{tabular}

Source: Soil analysis results, 2020.

\subsection{Annual cropping pattern on paddy fields}

Observation of the annual cropping pattern was carried out by observing the distribution of rainfall and rainy days that often occurred in the Tulang Bawang Regency area in the last five years. Observations show that the beginning of the rainy season usually occurs in December and ends in June of the current year. The custom of local farmers is to do initial planting (planting season-1) in December-January and ending March/April and planting season-2 in April/May of the current year. High rainfall can often delay planting time because the dominant land is inundated and even floods occur due to overflowing river water.

Figure 1 shows the distribution pattern of rainfall and rainy days during the year in the rainy season and the dry season in the study area. The annual cropping pattern in swampy rice fields is the first planting season (MT-1/MH): rice, the second planting season (MT-2/MK-1): corn/rice/secondary crops, the third planting season (MT-3/MK-2): secondary crops/idle depending on the conditions of the current season and the condition of the puddle. 


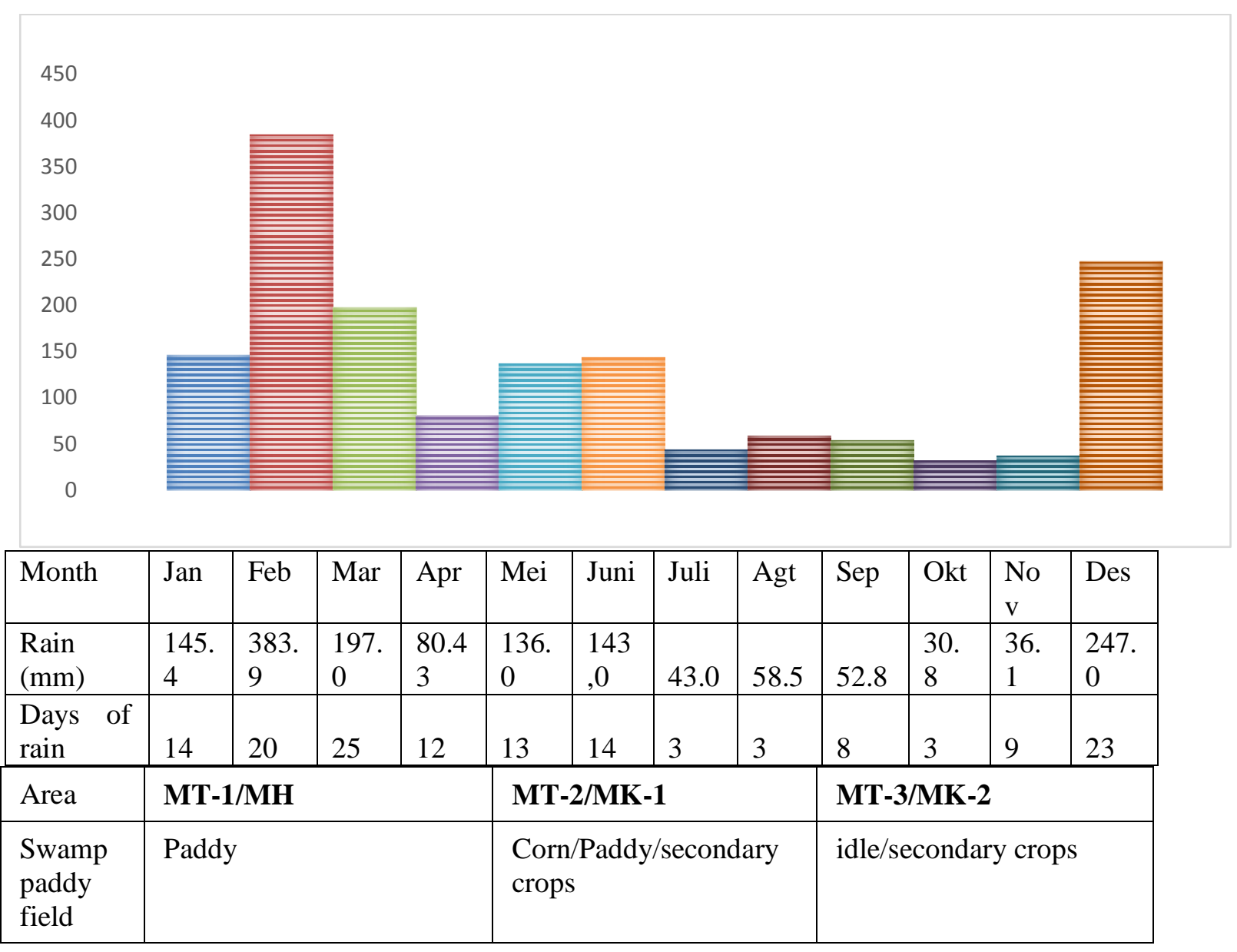

Figure 1. Annual Planting Patterns in the District of Dente Teladas, Tulang Bawang Regency

\subsection{Characteristics of Rice Farmers in Swamplands}

The results of a survey conducted on farmers in Teladas Village, Dente Teladas District, Tulang Bawang Regency showed the characteristics of farmers in swamps area (Table 2). To explore deeper, interviews were cunducted to obtain information by discussions or questions and answers regarding the information needed in accordance with the research objectives. The results of the analysis showed that the average farmer's age is 42 years, which means that the farmers in the local village were mature and had experiences in farming. Most of them had the level of education of Elementary School (SD). Thus, it still requires counseling guidance on their farming in order to obtain optimal results, especially from field officers. The average number of dependents in the family is 3 people, this condition has the potential to become a family worker who at times helps in farming.

Table 2. Characteristics of Farmers in Teladas Village, Dente Teladas District, Tulang Bawang Regency, 2020.

\begin{tabular}{cll}
\hline No. & Characteristics & Average $(\mathrm{n}=30)$ \\
\hline 1. & Age & 42 years \\
2. & Level of Education & 6 years (Elementary School) \\
3. & Family dependent & 3 people \\
4. & Main job & Paddy field owner or worker \\
5. & Farming experience & 24 years \\
6. & Other job & Farm laborer \\
\hline
\end{tabular}

Source: primary data, 2020. 
The results of the interview showed that the main job of the respondents was farmer which means that their daily livelihood relies on agricultural cultivation and farming activities. They did a side as a free farm laborer, which helps other peasants who need labor in managing the farm and usually get a wage from that. The average farming experience is 24 years, which means that the farmers in Teladas Village have enough experience in rice farming, in regard with how to cultivate rice on their tidal swamplands. The farmers interviewed through the survey are members of Karya Tani's farmer group (Poktan) in Marga Jaya, Teladas Village, Dente Teladas District, Tulang Bawangi Regency. Every year the farmers did rice farming in the first planting season, corn farming in the second planting season, and in the third planting season the land was often not planted (idle) due to limited availability of irrigation water. In the third planting season, farmers who cannot plant a commodity worked as agricultural laborers in annual crops or horticultural crops in the surrounding area which require labor in the third planting season farming management. The wages earned while working as a farm laborer are IDR 100,000/day per person and or around IDR 700,000/ha (with 6-7 people work per hectare). As additional information, the land rental fee for one hectare in the research area is IDR 2,500,000/year.

\subsection{Conditions of Technology Application in Farming}

The results of the interviews, which are reinforced by observations in the study area, showed an overview of the conditions of technology use in tidal swamp farming (Table 3). In Teladas Village, Dente Teladas Subdistrict, Tulang Bawang, the farmers used existing rice varieties in their area such like Ciherang and Cilamaya Muncul as well as local rice types that were often planted for years, there were also farmers growing hybrid rice types that were promoted from distributors. The choice of these varieties depends on their preferences and experience with the results obtained from planting rice varieties in the previous planting season. Some farmers even plant rice from the previous season's rice seeds if they feel the results are good to be used as seeds for the next season.

Soil cultivation technology was carried out conventionally by plowing, harrowing and leveling using a hand tractor. Planting manually uses human labor, often in a row of tiles with a certain spacing, most of which were about $27.5 \mathrm{~cm} \times 27.5 \mathrm{~cm}$. Regarding irrigation, it is also carried out in accordance with the farmer's method of making inlets and drains because the land is swampy. Irrigation canals are optimally useful when it occurs in the season of needing water, while when there is excess water, drainage channels are very vital.

Table 3. Application of Several Technology Components in Teladas Village, Dente Teladas District, Tulang Bawang Regency, 2020.

\begin{tabular}{rll}
\hline No. & Component & Technology \\
\hline 1. & Rice seeds & Cilamaya Muncul, Ciherang, Hybrid, Local \\
2. & Fertilization & Twice fertilizer application $(1 / 3$ and $2 / 3$ parts $)$, \\
& predominantly inorganic fertilizers, lime. \\
3. & Planting system & Tiles spacing $(27.5 \mathrm{~cm} \times 27.5 \mathrm{~cm})$ \\
4. & Pengolahan tanah & 1 time plow 2 times rakes \\
5. & Irrigation & conventional farmers, always inundated, need drainage \\
& disposal \\
6. & Pemeliharaan & disposal \\
7. & Harvest and post-harvest & conventional, the farmer's way \\
\hline
\end{tabular}

Source: primary data interview, 2020.

The management of rice plants was carried out conventionally according to the method and experience of each farmer, for the average plant fertilization is done twice during plant growth with a dose of $1 / 3$ part and $2 / 3$ part. The dosage of fertilization is according to the recommendation of the local extension workers, giving lime is usually done every 2 years. As for harvesting, the farmers were very familiar with where if the physiological ripening occurs (95\% yellowing). Harvest usually uses human labor or simple machines for farmers with limited capital. If the price of unhulled rice is felt, 
farmers usually sell directly in their rice fields to buyers. But if they do not find the right price, then harvest is carried out to be brought and stored at home first.

By observing the conditions of the implementation of technological innovations that tend to be limited in nature, efforts to increase the productivity of swamp rice are still open to be done. As a comparison, through the application of the innovative component of integrated crop management (PTT) of lowland rice, Lampung AIAT has proven successful in increasing rice productivity by 11.59 to $33.5 \%[19,20]$ The application of lowland rice PTT also has a positive impact on changes in farmers' income [21]. Acceleration and delivery of innovation through the Integrated Crop Management Field School (SLPTT) approach for lowland rice. Although according to research by [22], it is also in line with the evaluation of what is stated that the acceleration and adoption rate tends to be slow [12]. The choice of innovation components adopted by farmers occurs in interactions between the biophysical, social, cultural and economic aspects of the farmers and the characteristics of the innovation itself. The methods and patterns of dissemination of lowland rice PTT depend on the various characteristics of the innovation and the specific conditions of the region including swamps [23].

\subsection{Analysis of rice farming in swamp land}

The results of research and observations of the planting demonstration plot in the field showed that the growth and production of rice was quite good. If we look at the structure of rice farming in the Tulang Bawang area, Lampung, as shown in Table 4, it shows that the cost components of production facilities contributed $18.85 \%$ of the total farm cash costs incurred by farmers, while labor costs contributed $55.07 \%$ of the total cost of farming. The total cash cost of farming and land rent occupies a portion of $26.08 \%$ of the cash cost of farming. The total cash cost for farming was Rp. 9,587,000, - per hectare of farming land. Cash costs are costs that are actually incurred by farmers during their farming activities. Calculated costs are costs that have not actually been incurred but are calculated in the farm analysis. Of the two costs, the total cost of cash costs plus the calculated costs will be obtained. The cash cost in this analysis was IDR 9,587,000, while the cost was calculated as IDR 1,712,250. So the total production cost was IDR 11,299,250.

Labor costs occupies the highest portion of 55.07\%. In order to make it more efficient, of course, it needs to be spurred again by the use of technological innovations that can increase production. One of the innovations for farming on this land is the use of new superior varieties that have high yield and adaptive potential for swamps, balanced fertilization based on land fertility, and the calculation of the correct seasonal calendar. From the perspective of the farmer's household, it is necessary to know that in subsistence farming, the portion of the farm costs from the use of labor is the compensation for the wages of family workers which are not a lost, it can still be enjoyed as family income.

Based on the results of the analysis, it is known that rice farming in swampy fields carried out per hectare of farming land in Teladas Village, Dente Teladas District, Tulang Bawang Regency with the character of swampy rice fields and the implementation of farmers' innovations was able to produce an average production of $5,000 \mathrm{~kg}$ (Table 4). With the selling price per $\mathrm{kg}$ of unhulled rice of Rp. 3,300, it gives farm income of Rp. 16,500,000.

Rice farming in paddy filed of tidal swamp, if calculated based on the total production costs, gave a profit of Rp. 5,200,750, - with an R/C ratio of 1.46. And if it is calculated based on cash cost, it gave a profit of Rp. 6,913,000, - with an $\mathrm{R} / \mathrm{C}$ ratio of 1.72 . So, it can be concluded that rice farming in tidal swamplands is feasible. 
Table 4. Analysis of Paddy Farming in Teladas Village, Dente Teladas District, Tulang Bawang Regency, MT-2 in 2020

\begin{tabular}{|c|c|c|c|c|c|}
\hline No & Item & Unit & Total & $\begin{array}{c}\text { Unit Price } \\
\text { (IDR) }\end{array}$ & $\begin{array}{c}\text { Total Cost } \\
\text { (Rp) }\end{array}$ \\
\hline \multirow[t]{15}{*}{1.} & Production cost & & & & \\
\hline & Cash cost: & & & & \\
\hline & Seeds & & 4,00 & 120.000 & 480.000 \\
\hline & Manure & sack & 8,00 & 4.000 & 32.000 \\
\hline & Urea fertilizer & sack & 3,00 & 115.000 & 345.000 \\
\hline & NPK fertilizer & sack & 2,00 & 180.000 & 360.000 \\
\hline & $\mathrm{KCl}$ fertilizer & sack & 1,00 & 300.000 & 300.000 \\
\hline & SP-36 fertilizer & sack & 1,00 & 150.000 & 150.000 \\
\hline & Luiquid fertilizer & Botle & 2,00 & 70.000 & 140.000 \\
\hline & Workers outside family & person & 66,00 & 80.000 & 5.280 .000 \\
\hline & Land lease & IDR & 1,00 & 2.500 .000 & 2.500 .000 \\
\hline & Total cash cost & IDR & & & 9.587 .000 \\
\hline & Calculated cost: & & & & \\
\hline & Worker in the family & Person & 21,00 & & 1.680 .000 \\
\hline & Depreciation of tools & $\begin{array}{l}\text { IDR/planting } \\
\text { season }\end{array}$ & & & 32.250 \\
\hline \multirow[t]{2}{*}{2.} & $\begin{array}{l}\text { Total Production cost } \\
\text { Income: }\end{array}$ & IDR & & & 11.299 .250 \\
\hline & Rice production & $\mathrm{Kg}$. & 5.000 & 3.300 & 16.500 .000 \\
\hline 3. & Benefits of cash cost & IDR & & & 6.913 .000 \\
\hline \multirow[t]{2}{*}{4.} & $\mathrm{R} / \mathrm{C}$ Ratio on cash cost & & & & 1,72 \\
\hline & $\mathrm{R} / \mathrm{C}$ Ratio on total cost & & & & 1,46 \\
\hline
\end{tabular}

Source: Primary data analysis, 2020.

\section{Conclusions and Suggestions}

The cropping pattern for one year in tidal swamp paddy fields in Tulang Bawang Regency is rice in the first planting season, corn or rice or secondary crops in the second planting season and idle or secondary crops in the third planting season. The first planting season or the beginning of the rainy season (MH) is in December-January.

The results of the study showed that the growth and production of rice is quite good. Rice farming in the tidal wetland provides an advantage over a total cost of Rp. 5,200,750, - with an R/C ratio of 1.46 and an advantage over a cash cost of $\mathrm{Rp}$. 6,913,000, - with an $\mathrm{R} / \mathrm{C}$ ratio of 1.72 . So that rice farming in the tidal swampland is feasible.

Rice varieties planted by farmers in the Tulang Bawang area tend to use hereditary varieties (Ciherang, Cilamaya Muncul) with low yields. To increase production and income of lowland rice farmers in tidal swamps, it is necessary to implement innovation adoption, this adoption will easily occur through learning in the field. The technological innovation identified to increased production is the use of new superior varieties of rice specifically for swamps (Inpara).

In order to implement innovation in swampland rice cultivation to spread quickly and be adopted by farmers, it is necessary to develop extension/learning methods that make it easier for farmers to understand innovation so that it will lead to good perceptions of these innovations such as demonstration plots/farms, field laboratories, field schools and so on. Besides that, for innovationproducing institutions, it is best to create innovations that have favorable characteristics of swampland, uncomplicated, according to needs, easy to be tried, observed and communicated by farmers so that farmers will quickly adopt these innovations. 


\section{Acknowledgments}

Authors wishing to acknowledge Lampung AIAT and IAARD for the allocation of research costs. High appreciation goes to Heriyus Setiawan A.Md., Herna Suhartin A.Md, Yuli Setyo Rahayu A.Md., Sandi Nugroho, and Jumari for all assistance in carrying out field research.

\section{References}

[1] Rokhmah AN, Wening RH and Bobihoe J 2015 Genetic diversity of 17 local rice from Jambi Province based on morphological characterization and molecular markers. Proceedings of the 2014 National Seminar. Indonesian Center for Rice Research. Book-2 (Sukamandi: West Java) p 679-694

[2] Widjaja-Adhi IPG, Nugroho K, Suriadikarta DA and Karama AS 1992 Swamp Land Resources. Potential, Limitations and Utilization for Agricultural Development in Tidal and Lowland Swamps. (Cisarua: IAARD)

[3] Alihamsyah T 2002 Development Prospects and Tidal Land Utilization in Exploration Perspective of Future Agricultural Growth Sources. In I. Ar-Riza, T. Alihamsyah, and M. Sarwani (Eds). Groundwater Management in Tidal Lands. Monograph. ISSN 1410-637x. (Balittra) p 1-18

[4] Widjaja-Adhi IPG and Alihamsyah T 1999 Development of Tidal Land: Potential, Prospects and Constraints and Management Technology for Agriculture In the Proceedings of the East Java Soil Science Association Seminar (Bogor: Agricultural Socio-Economic Development) $p$ 148-153

[5] Widjaja-Adhi IPG, Suriadikarta DA, Sutriadi MT, Subiksa IGM and Suastika IW 2000 Management of utilization and development of swamps in the Book of Indonesian Land Resources and Management (Bogor: Soil and Agro-climate Research Center) p 127-164

[6] Hamzah MA 2014 Private support for the P2BN program Proceedings of the 2013 National Seminar: Adaptive Rice Technology Innovation to global climate change supports a surplus of 10 million tons of rice in 2014. (Sukamandi: Indonesian Center for Rice Research)

[7] Fagi AM, Abdullah B and Kartaatmadja S 2001 The role of Indonesian Rice in the development of superior rice Proceedings of Rice Culture (Bogor: Food Crops Research and Development Center)

[8] Suhartono, Artuti, AM, and Zarwan 2009 Appearance of superior rice varieties in deep acid fields. Proceedings of the National Seminar on the Application of Argo Innovations to Support Food Security and Agrobusiness (Bogor: Center for Food Crops Research and Development)

[9] Ruskandar A, Mulya SH, Triny SK, Wardana P and Las I 2007 Distribution of High Yielding Rice Varieties in Indonesia. In: Rice Industry, Culture and Environment Book 2 (Subang: Indonesian Center for Rice Research ICRR, IAARD)

[10] Jonharnas and Sembiring T 2007 Evaluation of Superior Paddy Varieties on Yield and Tungro Disease in Asahan. In IW. Profits, I.M. Trisawa, D. Praptomo, Jepri, R. Bakti, and Mulyawan (Eds). Proceedings of the National Seminar on the Support of Agricultural Technology in the Efforts to Increase Farm Production and Income. Research Institute for Agricultural Technology in the Bangka Belitung Islands. Pangkalpinang p 257-262.

[11] Sadjad SE, Murniati and Ilyas S 1999 Parameters of Seed Vigor Testing from Simulative Comparability (Jakarta: PT Gramedia Widiasarana Indonesia. Jakarta) 185 p.

[12] Sembiring H, Hakim L, Nyoman IW and Zaini Z 2012 Evaluation of Integrated Crop Management Adoption in Field Schools in the National Program for Increasing Food Crop Production. Penel National Seminar

[13] Rubiyo, Suprapto, and Drajat Aan 2005 Evaluation of several promising lowland rice lines in Bali. Germplasm Bulletin.Vol 11 No 1: 6-10

[14] Kustiyanto. 2001. Selection criteria for stress-tolerant traits of biotic and abiotic environments. Papers of Participatory breeding Research and Coordination (Shuttle Breeding) and Multilocation Test. Sukamandi.

[15] Satoto and Suprihatno B 2008 Hybrid Rice Development in Indonesia Food Crop Science and Technology Vol. 3(1) p 27-29 
[16] BPS Lampung Province 2018 Lampung in Numbers (Bandar Lampung : BPS Provinsi Lampung)

[17] BPS Tulang Bawang Regency 2019 Harvested Area, Yield and Rice Productivity Per Subround 2018-2019 Tulang Bawang In Numbers (Menggala: BPS Tlang Bawang Regency)

[18] Nazir M 2005 Research Methods (Jakarta: Ghalia Publisher)

[19] LampungAIAT 2010 Dissemination of Integrated Crop Management to Support the P2BN Program (Annual Report) (Bandar Lampung: Lampung AIAT)

[20] Pujiharti,Y, Muchlas, Ernawati and Wijayanto B 2008 Study on the Implementation of Rice Paddy Integrated Plant Management (PTT) in Lampung Proceedings of the Seminar on Research and Development of Site-Specific Agricultural Technology. Center for the Study and Development of Agricultural Technology in collaboration with Perhiptani Lampung and the Lampung Province Agriculture and Food Security Service

[21] Bananiek S And Abidin Z 2013 Socio-Economic Factors Affecting the Adoption of Integrated Paddy Rice Management Technology in Southeast Sulawesi Journal of the Assessment and Development of Agricultural Technology Vol 16(2) p 111-121

[22] Nurasa T and Supriadi H 2012 Field School Program for Integrated Rice Management (Performance and Anticipation of Policies to Support Sustainable Food Self-Sufficiency). Policy Analysis Vol 10(4) p 313-329

[23] Erythrina R, Indrasti and Muharam A 2013 Study of the Characteristics of Innovation in Technology Components to Determine the Pattern of Dissemination of Integrated Paddy Rice Management Journal of the Assessment and Development of Agricultural Technology Vo.16 (1) p 45-55 